\title{
The Stevia Rebaudiana Plant as Natural Sweetener with Antioxidant Properties
}

\author{
Rivka Weiser Biton \\ Prof. Ephraim Katzir Department of Biotechnology Engineering, ORT Braude College, Karmiel, Israel \\ (E-mail:rivkaw@braude.ac.il) \\ Gabriele Halevi \\ Schulich Faculty of Chemistry \\ Technion-Israel Institute of Technology, Haifa, Israel \\ (E-mail:gabriele@technion.ac.il)
}

\begin{abstract}
The worldwide use of Stevia rebaudiane as substitute sweetener for sugar, increases every year. Stevia rebaudiane is not involved in the insulin mechanism and as so has no calories. This makes Stevia rebaudiane also a natural substitute for the more common synthetic substitutes for sugar. Various studies show that the plant Stevia rebaudiane contains substances with properties of antioxidant reagent, and as such can prevent antioxidation damage to DNA. [1] In this work protocols for extraction are developed and antioxidating activity tested. The aim was to find optimal conditions for the process, so the antioxidants in the Stevia plant were preserved. Methods used for testing: Redox-titrations and spectrophothometric methods. In all results Vitamin $\mathrm{C}$ was used as reference for the antioxidation activity. The results show that the Stevia rebaudiane plant is active as an antioxidant reagent; and that the extent of the antioxidant activity depends on the solvent and on the conditions of the extraction process. In addition there was an attend to measure sweetness of the Stevia rebaudiane plant extract as function of the extraction process.
\end{abstract}

Keywords: Stevia rebaudiane, natural substitue for sugar, extraction process, antioxidating activity, methods for testing, sweetness

\section{Introduction}

Artificial sweeteners are the most widely used food additives [2]. The consumption is relative safe and can reduce the use of sugar-sweetened beverages, sweets, cakes without the impact of weight gain. Many people have turned to high-intensity sweeteners - but there is still a question if those food additives are safe?

Saccharin had shown no side effects in 120 years of use. Cyclamate also had not shown any side effects in over 70 years of use around the world- but is still banned in the USA. Sucralose seems safe for most people, except people who are allergic to it.

Aspartame is not safe because it is metabolized by the body and broken down to harmful products, one of them is Methanol.

\footnotetext{
Rivka Weiser-Biton, Dsc, Prof. Ephraim Katzir Department of Biotechnology Engineering, ORT Braude College, Karmiel, Israel

Gabriele Halevi, Schulich Faculty of Chemistry, Technion-Israel Institute of Technology, Haifa, Israel
} 
An additional problem is, that the study with mice showed us, that the mice were not satisfied with the artificial sweetener, instead they were pulled towards sweeter food rich in calories.

There is some evidence that frequent consumption of high intensity sweeteners may have a counterintuitive effect and increase risk of excessive weight gain and metabolic syndrome.

This leads to the assumption that the sweeteners cannot fill in for the "crave for sweets" [3].

The Stevia plant is a natural sweetener which is composed of 12 different kinds of sweeteners from the glycoside family[4] and has no influence on the blood sugar level. The plant is well known for its high sweet diterpene content (4-20\%) in dry mass, which includes Stevioside, Rebaudiosides A-F, and Dulcoside A. $5-10 \%$ of the dry Stevia plant is Stevioside [5] which is 200-300 times sweeter than Sucrose with a bitter aftertaste. $2-4 \%$ of the dry Stevia plant is Rebaudioside A which is 300-400 times sweeter than Sucrose with a mild aftertaste. $1-2 \%$ of the dry Stevia plant is Rebaudioside C, approximiately 30 times sweeter then Sucrose with a bitter aftertaste. $0.5-1 \%$ of the dry Stevia plant is Dulcoside A, also approximiately 30 times sweeter then Sucrose but with a very bitter aftertaste. Other kinds of the glycocides in the plant are not used as sweeteners. Sweetness is commonly measured by comparison to reference solutions of sucrose by human response.

The Stevia leaves are known as sugar leaves in South and Central America [6]. The leaves are used in South America to sweeten the "Mata" drinks and in Japan as substitute for sugar since 1971, Canada approved the Stevia plant as food additive. In addition there are commercial products which use only specific kind from the glycoside family, such as mainly Rebaudiosides A for Reb-A; a non calorie sweetener.

Polyalcohols with Rebaudiosides are used for Truvia, sweetener developed by Cargill and Coca-Cola. The name of the sweetener for Pepsi-Cola is Pure Via.

Can the Stevia plant offer more then being in use as a non - calorie sweetener? It turns out that the Stevia leaves contain substances which are antioxidant $[7,8]$. There are no reports so far about the antioxidant activity as function of the consumption of Stevia.

Antioxidant activity was studied in common plants [9]. Lertsiri [10] published a paper about different plants used as food and tested the antioxidative properties of those plants. He showed that the infusion from the Stevia plant had similar antioxidant properties to an infusion of green tea.

In addition Stevia rebaudiana leaves exhibited preventive activity against DNA strand scission by $\bullet \mathrm{OH}$, generated in Fenton's reaction.

In this work we will show the antioxidant activity of the Stevia plant compared to Vitamin C (Ascorbic acid). Vitamin $C$ is an electron donor, as such a potent water-soluble antioxidant in humans [11]. Antioxidant effects of Vitamin $\mathrm{C}$ have been demonstrated in many experiments in vitro. Oxidation of lipids, proteins and DNA results in specific oxidation products that can be measured in the laboratory.

\section{Why this Research?}

The purpose of the research is to characterize and to indentify the antioxidant properties of the Stevia plant as a function of the extraction process of the plant [12]. The main advantage of this research is the combination of sweetener and antioxidant activity found in the Stevia Rebaudiana plant.

In addition work with GL-1 sensors, which can measure sweetness, was done to find a connection between the degree of sweetness and suitable extraction processes. 


\section{Materials}

The antioxidant properties of Stevia were tested by a number of methods and compared to ascorbic acid. All of those methods measure amount of ascorbic acid.

Chemicals:

$\mathrm{C}_{2} \mathrm{H}_{5} \mathrm{OH}(\mathrm{aq}) 70 \%, \mathrm{KI}(\mathrm{aq}) 0.01 \mathrm{M}, \mathrm{KIO}_{3}, \mathrm{HCl}(\mathrm{aq}) 5 \mathrm{M}$, Starch $1 \%$, Ascorbic acid, $\mathrm{H}_{2} \mathrm{SO}_{4}(\mathrm{aq}) 0.125 \mathrm{M}$, Hydroxylamine hydrochloride $\left(\mathrm{NH}_{2} \mathrm{OH} \cdot \mathrm{HCl}\right)$,

$\mathrm{H}_{2} \mathrm{SO}_{3}(\mathrm{aq}), \mathrm{N}-(1-\mathrm{Naphthyl})$ ethylenediamine dihydrochloride (NEDA with $\left.2 \mathrm{HCl}\right), \mathrm{NaF}, \mathrm{K}_{3} \mathrm{Fe}(\mathrm{CN})_{6}(\mathrm{aq})$ $1 \%, \mathrm{FeCl}_{3}(\mathrm{aq}) 1 \%, \mathrm{H}_{3} \mathrm{PO}_{4}(\mathrm{aq}) 0.2 \%$,

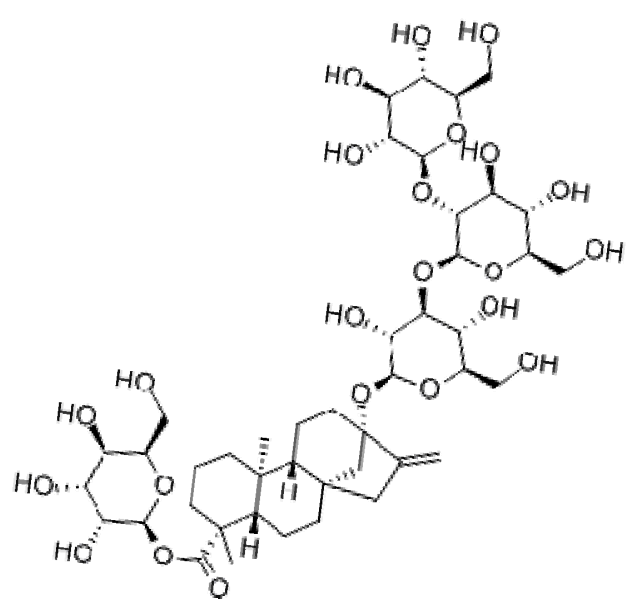

Rebaudioside A

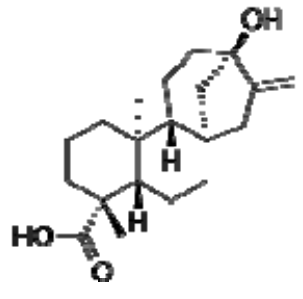

Steviol

Sucrazit classic - liquid, Sucrazit Stevia - powder

Plant materials:

Orange juice and peel, Lemon juice and peel,

Fresh leaves of Stevia, dried leaves of Stevia, dry leaves of Stevia from Nature Store

The sweetness of Stevia by a GL-1 sensor, which is sensitive to sucrose and other sugar related compounds.

Additional chemicals:

Stevioside as pure compound, Sucrose, $\mathrm{KCl}(\mathrm{aq}) 10 \mathrm{mM}$.

\section{Methods}

Determination of water percentage in fresh Stevia leaves:

Dry leaves are compared to fresh leaves- the main difference is the water content of the plant. Two drying methods were used: I.Weighting the plants before and after heating at $40^{\circ} \mathrm{C}$ for 2 weeks.

II.Weighting the plants before and after drying at room temperature for 4 weeks.

Comparison between the drying methods showed consistency. Both drying methods resulted in the same procentage of water in the plants.

\section{Extraction Methods}

Cold extraction, hot extraction with various temperatures, organic extraction $[13,14,15]$. 
Active carbon was added to all extraction of the stevia plant in order to accomplish clear and colourless solutions. Every cycle of extraction started with approxiemately 4 gram of Stevia plant and was repeated many times in order to allow at least four repetitions of each measuring method.

Procedure for cold extraction: a. weight the extract; $b$. add water as solvent; c. stir the solution for 6 hours at $25^{\circ} \mathrm{C}$; d. filter; e. transfer to volumetric flask.

Procedure 1 for hot extraction: a. weight the extract; $b$. add water as solvent; $c$. stir the solution for 1 hours at $75^{\circ} \mathrm{C}$; d. filter; e. transfer to volumetric flask.

Procedure 2 for hot extraction: a. weight the extract; b. add water as solvent; c. heat for 5 minutes at $95^{\circ} \mathrm{C}$; d. stir the solution for 55 minutes at $90^{\circ} \mathrm{C}$; e. filter f. transfer to volumetric flask.

Procedure 3 for hot extraction: a. weight the extract; b. add water as solvent; c. stir the solution for 5 minutes at $95^{\circ} \mathrm{C}$; d. filter; e. transfer to volumetric flask.

Procedure for organic extraction: a. weight the extract; b. add Ethanol $70 \%$-water $30 \%$ as solvent; c. stir the solution for 30 minutes at $70^{\circ} \mathrm{C}$; d. filter; e. transfer to volumetric flask; f. add Ethanol $70 \%$-water $30 \%$ till fill line.

Determination of Ascorbic acid by titration[16] :

1. Iodate $\left(\mathrm{IO}_{3}{ }^{-}\right)$oxidizes iodide $\left(\mathrm{I}^{-}\right)$to iodine $\left(\mathrm{I}_{2}\right): \mathrm{IO}_{3}{ }^{-}+5 \mathrm{I}^{-}+6 \mathrm{H}_{3} \mathrm{O}^{+} \rightarrow 3 \mathrm{I}_{2}+9 \mathrm{H}_{2} \mathrm{O}$

2. Iodine oxidizes Ascorbic acid $\left(\mathrm{C}_{6} \mathrm{H}_{8} \mathrm{O}_{6}\right): \mathrm{C}_{6} \mathrm{H}_{8} \mathrm{O}_{6}+\mathrm{I}_{2}+2 \mathrm{H}_{2} \mathrm{O} \rightarrow \mathrm{C}_{6} \mathrm{H}_{6} \mathrm{O}_{6}+2 \mathrm{H}_{3} \mathrm{O}^{+}+2 \mathrm{I}^{-}$

3. Starch-iodine endpoint : $\mathrm{I}_{2}$ forms blue complex with starch indicator

In this work the titration was done with three different concentrations of $\mathrm{KIO}_{3}$ in order to obtain a valid titration volume.

Every titration was repeated five times to achieve accurate results.

Determination of Ascorbic acid by Spectrophotometer:

Two methods: I. Determination by iron and Phenanthroline[17] measured at 420nm and II. Determination with Iodate at $540 \mathrm{~nm}$ gave no consistent results.

The formation of Prussian Blue is a classical qualitative test to detect $\mathrm{Fe}(\mathrm{II})$ using hexacyanoferrate(III) [18] as reagent. The procedure was successfully applied for the determination of Ascorbic acid by Mantei, Dorinas and Radu [19].

1. Oxidation of iron(II) :

$$
\mathrm{Fe}^{2+}+\left[\mathrm{Fe}(\mathrm{CN})_{6}\right]^{3-} \rightarrow \mathrm{Fe}^{3+}+\left[\mathrm{Fe}(\mathrm{CN})_{6}\right]^{4-}
$$

2. Formation of hexacyanoferrate (II) ferric insoluble complex (Prussian Blue):

$$
4 \mathrm{Fe}^{3+}+3\left[\mathrm{Fe}(\mathrm{CN})_{6}\right]^{4-} \rightarrow \mathrm{Fe}_{4}\left[\mathrm{Fe}(\mathrm{CN})_{6}\right]_{3}
$$

With the addition of $\mathrm{KCl} 0.1 \mathrm{M}$ and $\mathrm{HCl} 0.01 \mathrm{M}$ this reaction is quantative in low concentrations.

3. A deep blue soluble compound is formed when $\mathrm{Fe}(\mathrm{III})$ is reduced to $\mathrm{Fe}(\mathrm{II})$ by Ascorbic acid:

$$
2 \mathrm{Fe}^{3+}+\mathrm{C}_{6} \mathrm{H}_{8} \mathrm{O}_{6} \rightarrow 2 \mathrm{Fe}^{2+}+\mathrm{C}_{6} \mathrm{H}_{6} \mathrm{O}_{6}+2 \mathrm{H}^{+}
$$

The reduction of Prussian Blue reagent by Vitamin $\mathrm{C}$ is a $\mathrm{pH}$ dependent process. A steady-state signal for the spectrophotometer is reached after fiveteen minutes.

4. Prepararion of calibration curve with concentration of Ascorbic acid in the range of $0-20.000 \mathrm{mg} /$ liter.

5. Prussian Blue has an absorbance peak at $700 \mathrm{~nm}$.

Samples of Stevia leaves after organic extraction were not repeatable when measured by this spectroscopic method. 
Determination of the degree of sweetness of Stevia was tested by a calibrated GL-1 sensor. This sensor is a part of an artifical taste sensor - an e-tongue [20], which encludes the ability to "taste" - determine saltiness, sourness, bitterness and Umani. Those basic tastes are measured by a membrane by its electric density and hydrophobic property.

The calibration of the GL-1 sensor responses is based on a $10 \%$ sugar in water solutions and by human response. CT0 sensor for saltiness interferes with the signal for sweetness. When adding $10 \mathrm{mM} \mathrm{KCl}$ solution to the sample the signal for saltiness droppes and the GL-1 sensor signals get clearer.

\section{Results}

List of abbreviations:

STTC - fresh leaves of Stevia - cold extraction

STTH - fresh leaves of Stevia - hot extraction

STTO - fresh leaves of Stevia - organic extraction

STYC - fresh and dried leaves of Stevia - cold extraction

STYH - fresh and dried leaves of Stevia - hot extraction

STYO - fresh and dried leaves of Stevia - organic extraction

STKC - dry leaves of Stevia from nature store - cold extraction

STKH - dry leaves of Stevia from nature store - hot extraction

STKO - dry leaves of Stevia from nature store - organic extraction

A - Rebaudioside A

B - Steviol

VC - Vitamin C

SU - Sucrazit classic - liquid

SUST - Sucrazit Stevia - powder

Table 1

Water percentage in fresh Stevia leaves

\begin{tabular}{llll}
\hline Mass of fresh leaves [gram] & $\begin{array}{l}\text { Mass of drying process leaves } \\
\text { after drying process [gram] }\end{array}$ & Water content [\%] & Dry leaves [\%] \\
\hline 3.9961 & 0.4967 & 87.57 & 12.43 \\
3.9993 & 0.4976 & 87.56 & 12.44 \\
4.0010 & 0.4981 & 87.55 & 12.45 \\
\hline
\end{tabular}

standard deviation:0.01

All results are at least average of four repetitions. This measurement is important for comparison between dry leaves and fresh leaves, dried at room temperature.

Amount of Ascorbic acid relative to $1 \mathrm{mg}$ Vitamin $\mathrm{C}$ determent by titration: 
Table 2

\section{All titration results}

\begin{tabular}{|c|c|c|c|c|c|c|c|c|c|c|c|c|}
\hline & sample & $\begin{array}{c}\text { extraction } \\
\text { temperature } \\
{ }^{\circ} \mathrm{C}\end{array}$ & $\begin{array}{c}\text { extraction } \\
\text { time } \\
\text { min }\end{array}$ & weight & $\begin{array}{c}\text { weight } \\
\text { after drying } \\
\text { mg }\end{array}$ & $\begin{array}{c}\text { volumetric } \\
\text { flask } \\
\mathrm{ml}\end{array}$ & $\begin{array}{c}\begin{array}{c}\text { concentration } \\
\text { of sample }\end{array} \\
\mathrm{mg} / \mathrm{ml}\end{array}$ & $\begin{array}{c}\begin{array}{c}\text { volume } \\
\text { of sample }\end{array} \\
\mathrm{ml}\end{array}$ & $\begin{array}{c}\text { weight } \\
\text { of sample } \\
\text { for titration } \\
\mathrm{mg}\end{array}$ & $\begin{array}{c}\text { volume } \\
\text { of titrant } \\
* * * / \# \# \\
\mathrm{ml}\end{array}$ & $\begin{array}{c}\text { volume } \\
\text { needed for } \\
1 \mathrm{mg} \mathrm{of} \mathrm{sample} \\
\mathrm{ml}\end{array}$ & $\begin{array}{l}\text { antioxidant activity } \\
\text { relative to } 1 \mathrm{mg} \\
\text { vitamin C }\end{array}$ \\
\hline$* * * 1$ & STKH & 75 & 60 & 4012.5 & & 100 & 40.125 & 20 & 802.5 & 0.160 & $1.99 \mathrm{E}-04$ & $2.36 \mathrm{E}-04$ \\
\hline$* * * 2$ & STKH & 90 & 60 & 4012.5 & & 100 & 40.125 & 20 & 802.5 & 0.160 & $1.99 \mathrm{E}-04$ & $2.36 \mathrm{E}-04$ \\
\hline$* * * 3$ & STKH & 95 & 5 & 4012.5 & & 100 & 40.125 & 20 & 802.5 & 0.240 & $2.99 \mathrm{E}-04$ & $3.54 \mathrm{E}-04$ \\
\hline$* * * 4$ & STKC & 25 & 420 & 1999 & & 100 & 19.990 & 20 & 399.8 & 0.145 & 3.63E-04 & $4.29 \mathrm{E}-04$ \\
\hline$\# 5$ & STKO & 70 & 30 & 3990 & & 50 & 79.800 & 10 & 798.0 & 0.980 & $1.23 \mathrm{E}-03$ & $1.45 \mathrm{E}-03$ \\
\hline$* * * 6$ & STYH & 90 & 60 & 4012 & & 100 & 40.120 & 20 & 802.4 & 0.220 & $2.74 \mathrm{E}-04$ & $3.24 \mathrm{E}-04$ \\
\hline$* * 7$ & STYH & 95 & 5 & 4012.5 & & 100 & 40.125 & 20 & 802.5 & 0.270 & $3.36 \mathrm{E}-04$ & $3.98 \mathrm{E}-04$ \\
\hline$* * * 8$ & STYC & 25 & 420 & 4012.5 & & 100 & 40.125 & 20 & 802.5 & 0.330 & 4.11E-04 & $4.86 \mathrm{E}-04$ \\
\hline$\# 9$ & STYO & 70 & 30 & 400 & & 50 & 8.000 & 10 & 80.0 & 0.430 & $5.38 \mathrm{E}-03$ & $6.36 \mathrm{E}-03$ \\
\hline$* * * 10$ & STTH & 90 & 60 & 4012 & 499.1 & 100 & 4.991 & 20 & 99.8 & 0.032 & $3.21 \mathrm{E}-04$ & $3.79 \mathrm{E}-04$ \\
\hline$* * * 11$ & STTH & 95 & 5 & 4034 & 501.8 & 100 & 5.018 & 20 & 100.4 & 0.039 & $3.89 \mathrm{E}-04$ & $4.60 \mathrm{E}-04$ \\
\hline$* * * 12$ & STTC & 25 & 420 & 4034 & 501.8 & 100 & 5.018 & 20 & 100.4 & 0.052 & $5.18 \mathrm{E}-04$ & $6.13 \mathrm{E}-04$ \\
\hline$\# 13$ & STTO & 70 & 30 & 3720 & 462.8 & 50 & 9.255 & 10 & 92.6 & 0.700 & $7.56 \mathrm{E}-03$ & $8.95 \mathrm{E}-03$ \\
\hline$* * * 14$ & SU & 25 & 420 & 8000 & & 50 & 160.000 & 20 & 3200.0 & 0.135 & $4.22 \mathrm{E}-05$ & $4.99 \mathrm{E}-05$ \\
\hline$* * * 15$ & SUST & 25 & 420 & 8000 & & 100 & 80.000 & 20 & 1600.0 & 0.170 & $1.06 \mathrm{E}-04$ & $1.26 \mathrm{E}-04$ \\
\hline$* * * 16$ & A & 25 & 420 & 100 & & 100 & 1.000 & 20 & 20.0 & 0.170 & $8.50 \mathrm{E}-03$ & $1.01 \mathrm{E}-02$ \\
\hline$* * * 17$ & B & 25 & 420 & 10 & & 50 & 0.200 & 20 & 4.0 & 0.037 & $9.25 \mathrm{E}-03$ & $1.09 \mathrm{E}-02$ \\
\hline 18 & VC & & & 104.2 & & 100 & 1.042 & 20 & 20.8 & 17.620 & $8.45 \mathrm{E}-01$ & $1.00 \mathrm{E}+00$ \\
\hline
\end{tabular}

\#\# The titrant was diluted 20 fold to obtain valid titration volume

*** The titrant was diluted 100 fold to obtain valid titration volume

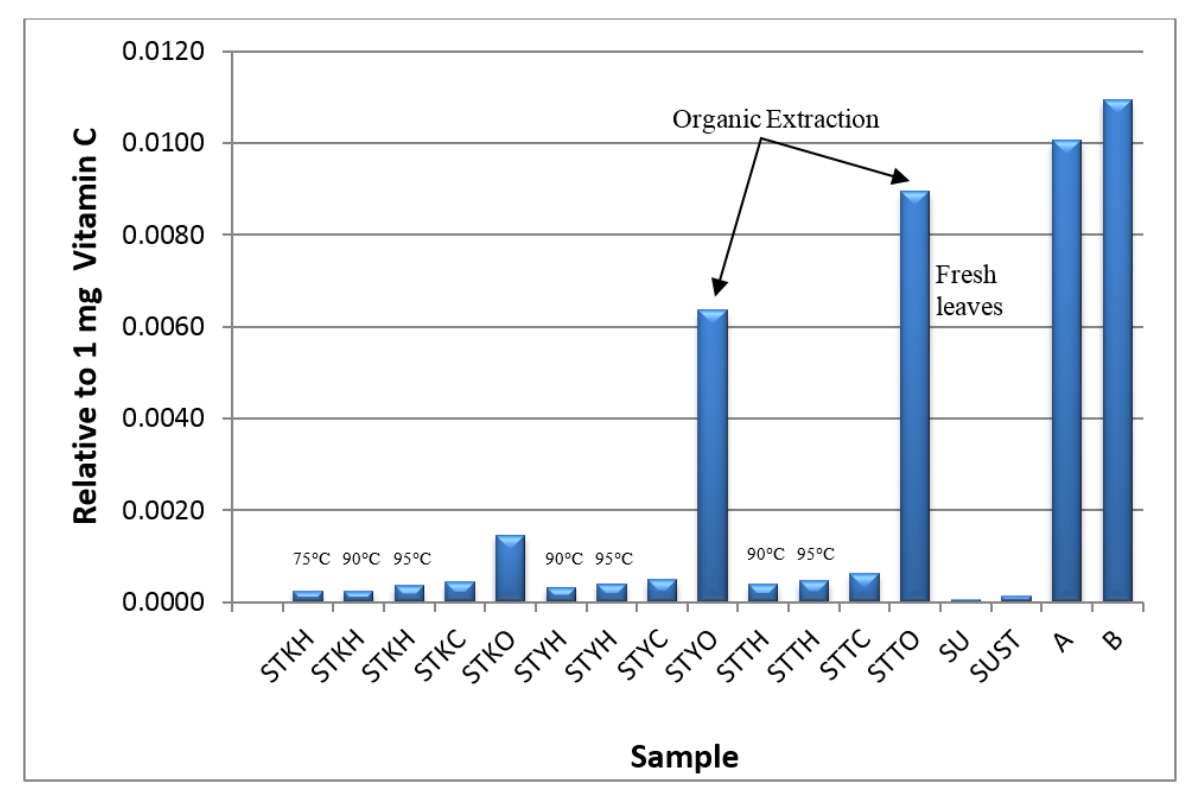

Figure 1. Antioxidant Activity of all Samples as a function of the Activity in $1 \mathrm{mg}$ Vitamin C determent by Titration.

The most antioxidant activity was found in Steviol, Rebaudioside A, and in fresh leaves after organic extraction (Fig.1.). Leaves which were dried in the laboratory also contained more antioxidants than dry leaves which were bought in a store.

For the fresh leaves the most efficient extraction by far is the organic extraction (Fig.2.). 


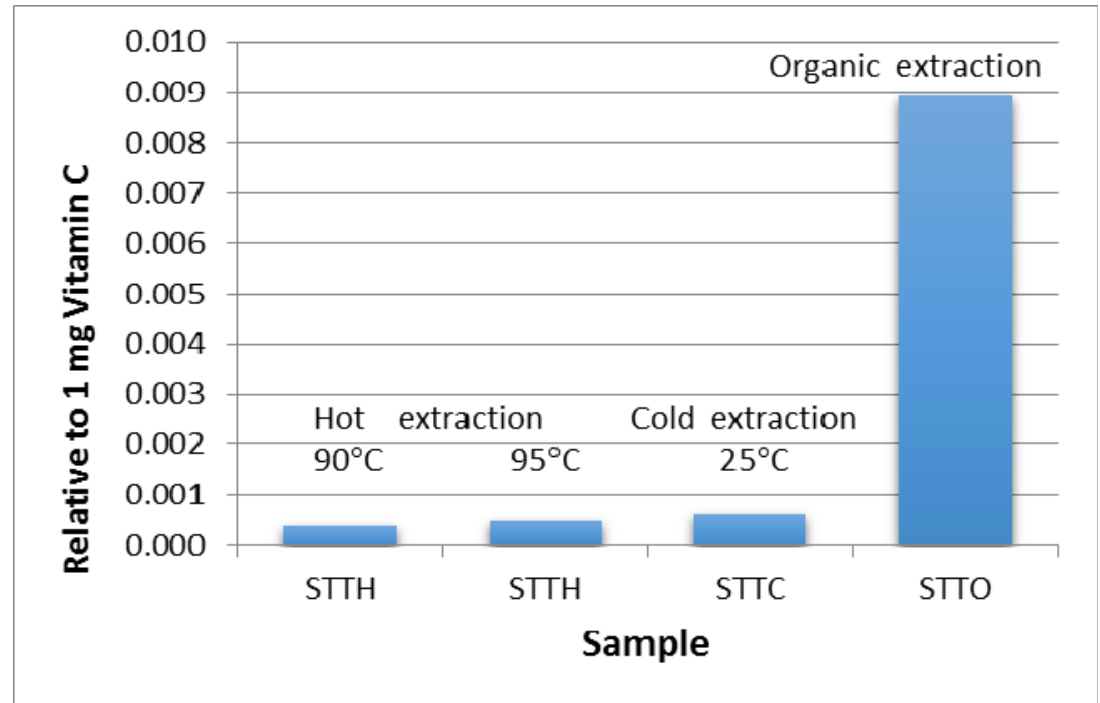

Figure 2. Antioxidant activity in freah Stevia leaves as function of extraction method.

For Calibration curve: various concentration of Ascorbic acid 1·10-4M (17.6mg/liter) solution:

Table 3

Calibration curve of Vitamin C with Prussian Blue Complex at 700nm

\begin{tabular}{|c|c|c|c|c|c|c|}
\hline flask no. & $\begin{array}{l}\mathrm{FeCl}_{3} \\
5 * \mathrm{E}-3 \mathrm{M}[\mathrm{ml}] \\
\end{array}$ & $\begin{array}{l}\mathrm{KCl} 1.0 \mathrm{M} \\
{[\mathrm{ml}]}\end{array}$ & $\begin{array}{l}\mathrm{HCl} 0.1 \mathrm{M} \\
{[\mathrm{ml}]}\end{array}$ & $\begin{array}{l}\text { Ascorbic acid } 176 \mathrm{mg} / \mathrm{L} \\
(1 * \mathrm{E}-3 \mathrm{M})[\mathrm{ml}]\end{array}$ & $\begin{array}{l}\text { Concentration of Ascorbic } \\
\text { acid in } 10 \mathrm{ml}[\mathrm{mg} / \mathrm{ml}]\end{array}$ & O.D. \\
\hline 1 & 1 & 1 & 1 & 0.1 & 1.76 & 0.051 \\
\hline 2 & 1 & 1 & 1 & 0.2 & 3.52 & 0.071 \\
\hline 3 & 1 & 1 & 1 & 0.3 & 5.28 & 0.134 \\
\hline 4 & 1 & 1 & 1 & 0.4 & 7.04 & 0.217 \\
\hline 5 & 1 & 1 & 1 & 0.5 & 8.8 & 0.298 \\
\hline 6 & 1 & 1 & 1 & 0.6 & 10.56 & 0.34 \\
\hline 7 & 1 & 1 & 1 & 0.7 & 12.32 & 0.414 \\
\hline 8 & 1 & 1 & 1 & 0.8 & 14.08 & 0.432 \\
\hline 9 & 1 & 1 & 1 & 0.9 & 15.84 & 0.493 \\
\hline 10 & 1 & 1 & 1 & 1 & 17.6 & 0.551 \\
\hline
\end{tabular}

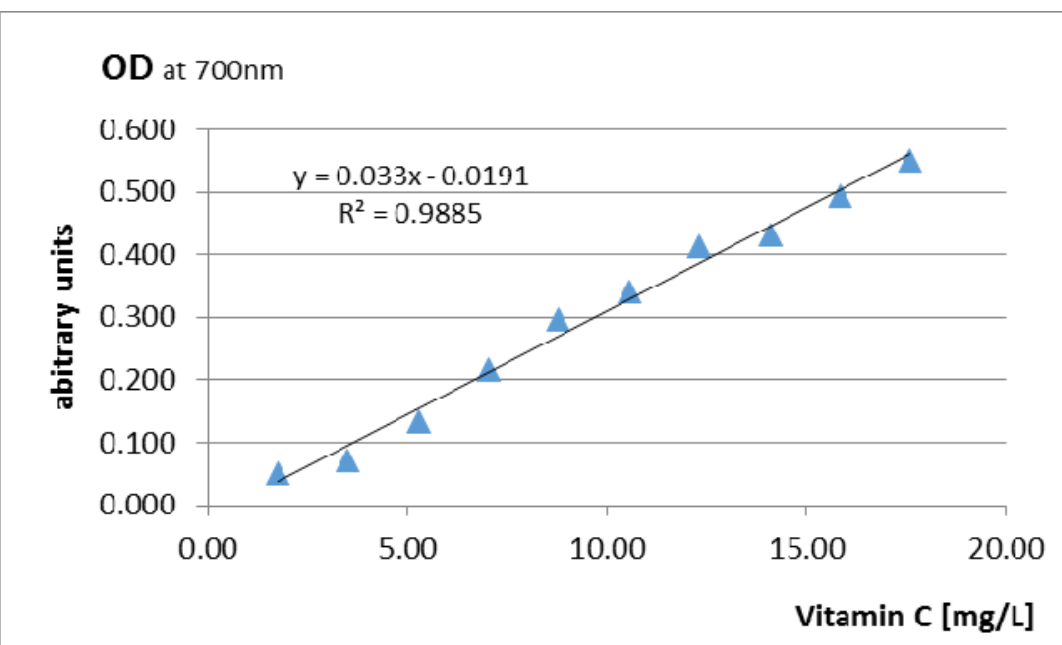

Figure 3. Calibration curve of Vitamin C with Prussian Blue Complex at 700nm. 
Table 4

Results of spectrophotometric method using the Prussian Blue complex and measured at 700nm

\begin{tabular}{|c|c|c|c|c|c|c|c|c|c|c|c|c|}
\hline sample & $\begin{array}{c}\text { extraction } \\
\text { temperature } \\
{ }^{\circ} \mathrm{C} \\
\end{array}$ & $\begin{array}{c}\text { extraction } \\
\text { time } \\
\text { min } \\
\end{array}$ & weight & \begin{tabular}{|c|} 
weight \\
after drying \\
mg
\end{tabular} & $\begin{array}{c}\text { volumetric } \\
\text { flask } \\
\mathrm{ml}\end{array}$ & $\begin{array}{c}\begin{array}{c}\text { concentration } \\
\text { of sample }\end{array} \\
\mathrm{mg} / \mathrm{ml}\end{array}$ & $\begin{array}{c}\text { volume } \\
\text { of sample } \\
\mathrm{ml}\end{array}$ & $\begin{array}{l}\text { volume with } \\
\text { Prussian blue }\end{array}$ & $\begin{array}{c}\text { weight } \\
\text { of sample } \\
\text { for spectro } \\
\text { mg }\end{array}$ & $\mathrm{OD}$ & $\begin{array}{l}\text { concentration of } \\
\text { ascorbic acid by } \\
\text { calibration curve } \\
\mathrm{mg} / \mathrm{L}\end{array}$ & $\begin{array}{l}\text { antioxidant activity } \\
\text { relative to } 1 \mathrm{mg} \\
\text { vitamin C }\end{array}$ \\
\hline STKH & 90 & 60 & 3920 & & 100 & 39.200 & 5 & 10 & 19.6 & 0.217 & 7.155 & $3.650 \mathrm{E}-04$ \\
\hline STKH & 95 & 5 & 3900 & & 100 & 39.000 & 5 & 10 & 19.5 & 0.298 & 9.609 & 4.928E-04 \\
\hline STKC & 25 & 420 & 3920 & & 100 & 39.200 & 5 & 10 & 19.6 & 0.309 & 9.942 & $5.073 \mathrm{E}-04$ \\
\hline STYH & 95 & 5 & 4000 & & 100 & 40.000 & 5 & 10 & 20.0 & 0.372 & 11.852 & $5.926 \mathrm{E}-04$ \\
\hline STYC & 25 & 420 & 4120 & & 100 & 41.200 & 5 & 10 & 20.6 & 0.416 & 13.185 & $6.400 \mathrm{E}-04$ \\
\hline STTH & 90 & 60 & 4140 & 515.0 & 10 & 51.502 & 5 & 10 & 25.8 & 0.478 & 15.064 & $5.850 \mathrm{E}-04$ \\
\hline STTH & 95 & 5 & 3720 & 462.8 & 10 & 46.277 & 5 & 10 & 23.1 & 0.426 & 13.488 & $5.829 \mathrm{E}-04$ \\
\hline STTC & 25 & 420 & 4360 & 542.4 & 10 & 54.238 & 5 & 10 & 27.1 & 0.593 & 18.548 & $6.840 \mathrm{E}-04$ \\
\hline
\end{tabular}

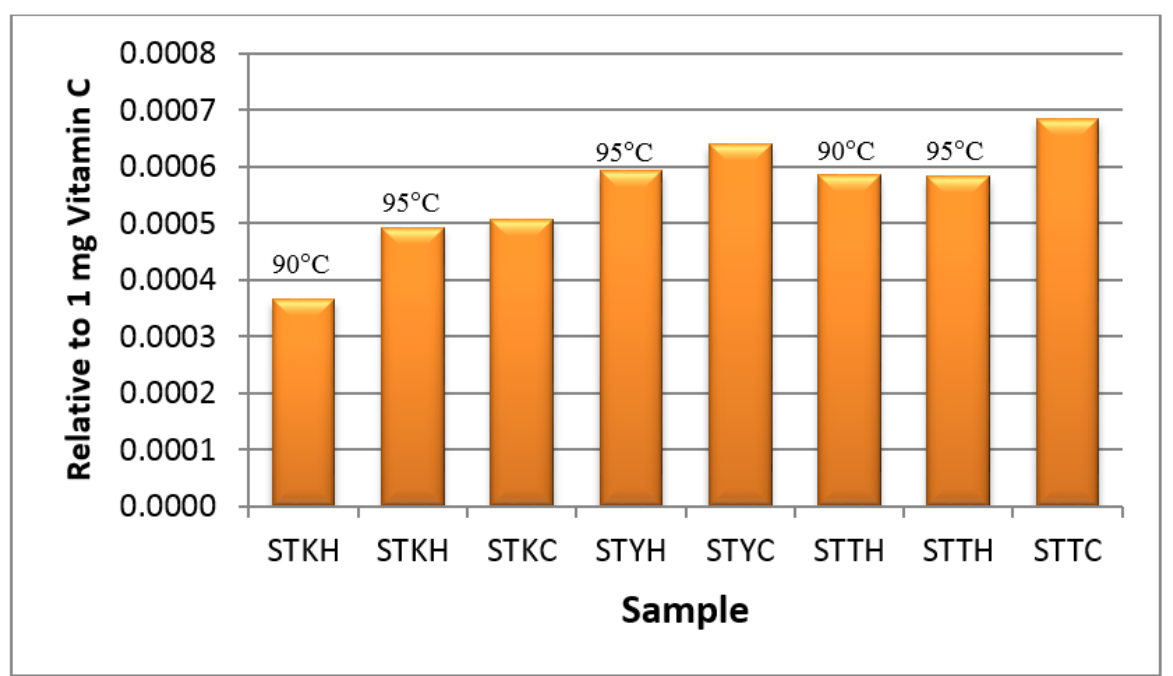

Figure 4. Antioxidant Activity of all Samples as a function of the Activity in $1 \mathrm{mg}$ Vitamin C determent by Prussian Blue Complex at $700 \mathrm{~nm}$.

The most antioxidant activity was found in fresh leaves after cold extraction (Fig.4.). Leaves which were dried in the laboratory also contained more antioxidants than dry leaves which were bought in a store.

The concentration of leaves after organic extraction could not be measured by this spectrophotometric procedure.

Primalary results show that sweetness can be measured by GL1-Sensors. The results also show a correlation between sweetness and extraction processes [21,22].

\section{Discussions and Conclusions}

The basic idea of this work was to use the Stevia plant as sweetener and at the same time as antioxidizing reagent. This was the reason, first to study the antioxidizing potential of the Stevia plant compared to a known antioxidizing reagent: Ascorbic acid (Vitamin C). Second to study how to use the Stevia plant while guarding its properties, sweetness and antioxidizing potential. Significant for the way of using the plant are: kind of leaves (fresh or dried) and kind of extraction.

At the lab all kind of Stevia leaves were tested - fresh and dried in a few ways; so were different kind of extraction tested as cold, hot extraction at different temperatures and at a different time of extraction. In 
addition organic extraction was tested. The purpose of all of the tests were to understand how those methods effect the antioxidizing activity of the plant.

The results of this research show that the cold extraction of all kind of Stevia leaves is preverable over the hot extraction as function of antioxidant activity; so is the five minute hot extraction preverable over a thirty minute hot extraction. In other words the extraction of Stevia leaves suits cold beverages, which can contain also sweetness and antioxidizing activity. In hot beverages and baking, because of the temperature, most of the antioxidizing activity is lost $[9,10]$.

The results also show that the most effective extraction is the organic one. In addition the fresh leaves show more antioxidizing activity then the dry leaves (bought or dried in the lab) which was consistent in all kind of extractions (cold, hot and organic). Comparing the dry leaves of the Stevia plant, the one dried at the lab had more antioxidizing activity then the one bought.

Steviol and Rebaudioside A, which origin in the Stevia leaves were also tested. Steviol was found more antioxidizing active than Rebaudioside A. So the Sucrazit Stevia (SUST) was found more antioxidizing active then the Sucrazit (SU), both are widely used as food additives. Again the Stevia plant contributes to the antioxidizing activity.

In this work we compare Steviol and Rebaudioside A, which were pure compounds bought from Fluka Analytical, to the dry and fresh leaves of the Stevia plant. That is to say that $1 \mathrm{mg}$ of pure material was compared to $1 \mathrm{mg}$ crude compound, so it was expected that the pure material will show more antioxidizing activity.

In addition there should be a standart lab test in pursuance to find a connection between antioxidant properties, sweetness and extraction processes.

In the future it is important to analyze the antioxidant properties as function of different species of the stevia plant and also as function of various conditions of their growth.

Performing statistical processing will enable the optimization of plant species and growing conditions.

\section{References}

F.M. Kengne, A.L. Woguia, P. Fogue Souopgui, B. Atogho-Tiedeu, G. Simo, B. Thaddée. Journal of Coastal Life Medicine, 2 (12), 962-969, 2014.

Merck Index, $11^{\text {th }}$ Edition, 8282.

S.E. Swithers. Artificial Sweeteners produce the counterintuitive Effect of inducing metabolic Derangements, Trends Endocrinology and Metabolism, 24 (9), 431-441, Sep. 2013.

Varki A et al. Essentials of Glycobiology, Cold Spring Harbor Laboratory Press, 1999.

S. Kailasam. Quantifi Cation of Stevioside and Rebaudioside A in Stevia Rebaudiana Bertoni Leaves using Agilent 1260 Infinity LC, Agilent Technologies, 1-4 (2011).

U. Woelwer-Rieck, C. Lankes, A.Wawrzun, M. Wüst. Improved HPLC Method for the Evaluation of the major Steviol Glycosides in Leaves of Stevia rebaudiana, Springer Verlag, Eur Food Res Technol, 231, 581-588, 2010.

J.S. Valentine, C.S. Foote, A. Greenberg and J.F. Liebman Eds., Active Oxygen in Biochemistry, Search Series Vol. 3, Blackie Academic \& Professional, London, 1995.

M. Valko, D. Leibfritz, J. Moncol, M. Cronin, M. Mazur, J. Telser. Free Radicals and Antioxidants in normal physiological Functions and Human Disease, The International J. of Biochemistry\&Cell Biology, 39 (1), 44-84, 2007.s.

N.A. Khalaf, A.K. Shakya, A. Al-Othman, Z. El-Agbar, H. Farah. Antioxidant Activity of Some Common Plants, Turk J. Biology, 32, 51-55, 2008.

P. Deetae, P. Parichanon, P. Trakunleewatthana, C. Chanseetis, S. Lertsiri. Antioxidant and anti-Glycation Properties of Thai herbal Teas in Comparison with conventional Teas, Food Chemistry, 133, 953-959, 2012. 
S.J. Padayatty, A. Katz, Y. Wang, P. Eck, O. Kwon, J.H. Lee, S. Chen, C. Corpe, A. Dutta, S.K. Dutta, M. Levine. J. of the American College of Nutrition, 22 (1), 18-25, Feb. 2003.

I.A. Jahan, M. Mostafa, H. Hossain, I. Nimmi, A. Sattar, A. Alim and Syed M.I. Moeiz. Bangladesh Pharmaceutical Journal, 13 (2), 67-75, July 2010.

S. Singh, V. Garg, D. Yadav, M. Nadeem Beg, N. Sharma. In vitro antioxidative and antibacterial Activities of various Parts of Stevia rebaudiana (Bertoni), International J. of Pharmacy and Pharmaceutical Sciences, 4 (3), 468-473, 2012.

Sh. Shukla, A. Mehta, V.K. Bajpai, Sa. Shukla. In vitro Antioxidant Activity and total phenolic Content of ethanolic leaf Extract of Stevia rebaudiana Bert, Experimental and Toxicologic Pathology, 47, 2338-2343, 2009.

S. Shukla, A. Mehta, P. Mehta, V.K. Bajpai. Antioxidant Ability and total phenolic Content of aqueous leaf Extract of Stevia rebaudiana Bert, Experimental and Toxicologic Pathology, 64, 807-811, 2012.

Determination of Vitamin C Concentration by Titration, University of Canterbury, Christchurch, New Zealand.

J. Anwar, M.I. Farooqi, S.A. Nagra and A.M. Khan. A new Method for Spectrophotometric Determination of Ascorbic Acid, Jour. Chem. Soc. Pak., 12 (1), 76-79, 1990.

L.N. Jattinagoudar, K.S. Byadagi, N.M. Shirhatti, S.T. Nandibewoor and S.A. Chimatadar. J. of Chemical and Pharmaceutical Research, 5 (4), 290-300, 2013.

N. Matei, S. Dobrinas, G.L. Radu. Spectrophotometric Determination of Ascorbic Acid in Grapes with the Prussian Blue Reaction, Ovidius University Annals of Chemistry, 23 (1), 174-179, 2012.

Taste Sensor Intermediate User's Guide, Intelligent Sensor Technology, Inc.

K. Toyota, H. Cui, K. Abe, M. Habara, K. Toko, H. Ikezaki. Sweetness Sensor with Lipid/Polymer Membranes: Response to Various Sugars, Sensors and Materials, 23 (8), 475-482,2011.

M. Yasuura, Y. Tahara, H. Ikezaki, K. Toko. Development of a Sweetness Sensor for Aspartame, a Positively Charged High-Potency Sweetener, Sensors, 14, 7359-7373, 2014. 